\title{
New Technologies of Cultural Regeneration. An Exemple of Sanfelice Staircase as a Place of Comunication
}

\author{
Valeria Marzonchella \\ Maurizio Perticarini
}

\section{Abstract}

The staircase has always been an indispensable element in architecture. The type of Neapolitan open staircase, represented in the cinema and theatre, becomes part of the scenography enriching the scene and offering different points of view to the frames, generating chiaroscuro and, with its pierced façade, sparking space-perceptual continuity between the courtyard (internal space) and the street (external space). It forms a spatial dam which represents several factors that are realized and manifested in it: by adding the screenplay and the actors, a new and unusual complex is obtained, as happens in the film Miseria e Nobiltà (1954), in which the fusion of the comedy and the architecture of solids and voids, with the well-staircase, poses a constantly changing harmonic resultant. A mutation that, years later, becomes a necessity with the use of the lift, which generates a new concept of collective fruition, a further point of view, intimate but useful as a space (scene) for immersive events made with new technologies. The aim of the project is to bring the public into the private courtyards of the buildings and create shows using the potential of augmented reality or video mapping. In the case of Naples, the idea is to take inspiration from the Neapolitan art comedy, but the general intent is to bring this type of representations to other contexts (examples of open stairs in Europe mentioned in the article), changing each time the theme of the show reproduced.

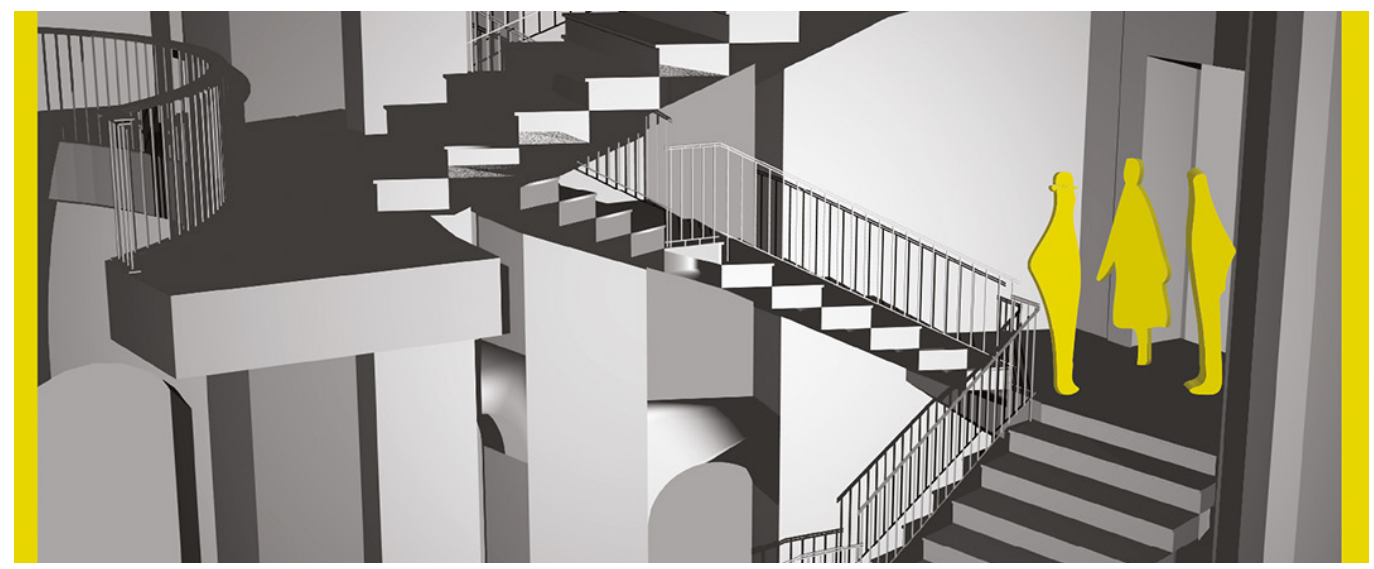




\section{Introduction}

For its function linked to the act of 'going up', the staircase has always played an important role in the field of architecture, it is as old as architecture itself, several significant examples can be cited throughout history which allow to understand its profound importance, just think of the Mayan pyramid Nohoch Mul of Quintana Roo, Mexico, those of the Palace of Knossos in Crete, Greece and the Necropolis of Myra an ancient Greek city that was in ancient Lycian and in current Turkey, today Demre. Subsequently in the Baroque period, the staircase moved from the design ideology to a space-time configuration representative of architecture, including and merging monumental but also imaginative dimensions together. In the 18th century in Italy and especially in Naples, the concept of stairs changed over time and it became a representative space of architecture [Zerlenga 20I4]. Inside the historic Neapolitan building, the staircase is part of a system of access between public and private, consisting of a road-portal-entrance hall-courtyard-staircase and is placed as the basic element of this spatial sequence. The small outdoor space does not allow to focus the entire facade of the building, so the passer-by is led to peek into the interior of the building, finding, after the portal, the staircase as the second main element [Zerlenga 2000]. The curiosity induced in the spectator is attributable to the spatial and ideological configuration of the Roman Domus.
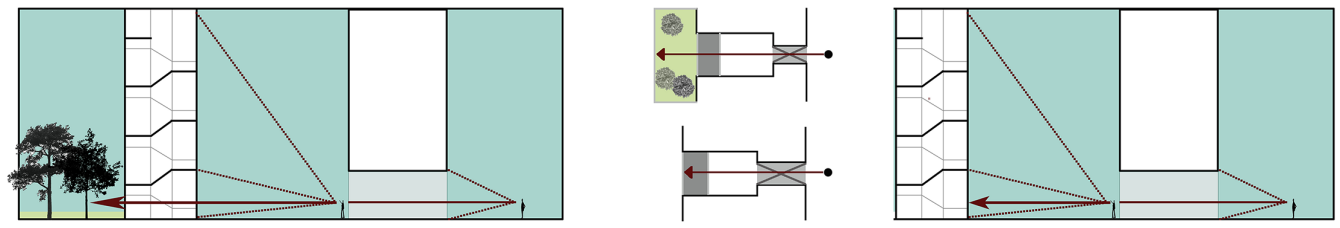

\section{Dialogue and Environment: architectural environment of the access system}

During the eighteenth century, in Naples, the portal and the staircase of the buildings took on an attractive role as a real scenography where the first one acts as a proscenium and is the first ring in a continuous spatial sequence willing to mark the passage from a public space (the street) to a private one (the building) while the second one acts as a background [Zerlenga 20 I3]. Its plastic-figurative configuration, the alternating scan of light-shadow-light allows the succession of street-entrance hall-courtyard to be read at the same time, attracting the attention of the passer-by who, having passed the entrance hall, turns the gaze into a gathered area (the courtyard), an open-air space where in most of the 18th century Neapolitan buildings there is an open staircase, often located in front of the entrance, with the intention of visually seducing the passer-by. The spatial dynamism is generated by the changing course of the flights, by the variously articulated vaulted structures and by the pierced walls that lead the curious eye over the staircase to the courtyard generating multiple points of view, obtaining a multidimensional perceptual context [Zerlenga 20 I 6] (fig. I). The architectural complexity of the staircase in the theatrical and cinematographic field tends to overturn. The access system is not seen from the outside, but the point of view starts from the apartment continuing in reverse with the staircase - courtyard - entrance hall - portal - external street. In the specific case of the comedy Miseria e Nobiltà, the scenes open in an apartment, where the protagonists of the story are introduced. The observer's attention focuses on the setting which helps him to add other key elements, useful for a correct understanding of the scene. Subsequently, the attention shifts to the staircase that acts as a scenery for the actors, dividing various time sequences, where each group of actors is assigned a specific position to capture the inexhaustible points of view generated by the stair- 
case. The staircase becomes the real stage with different altimetric levels, in this sense the vision moves towards the vertical plane enriching the scene with new multiple perspectives, transforming itself from a static element to a dynamic one, accompanying the movement of the recital of the actors and also giving different points of view to the video footage. The side scenes and the backdrop have an illusionistic role and set the background of the dialogues that take place outside the portal. The latter, being in the stage-front and becoming the proscenium, has a fundamental role: embrace the dialogues and enrich them with its shape, its material, and its majesty. It acts as a glue between two sceneries, creating a double background that pierces the floors, alluding to a profound perspective such as Borromini's illusionist one at Palazzo Spada, Rome (1635) (fig. 2) trompe-l'oeil masterpiece of false perspective. It is located at the entrance hall to the courtyard and consists of a sequence of columns of decreasing height which, together with the floor that rises, generates the optical

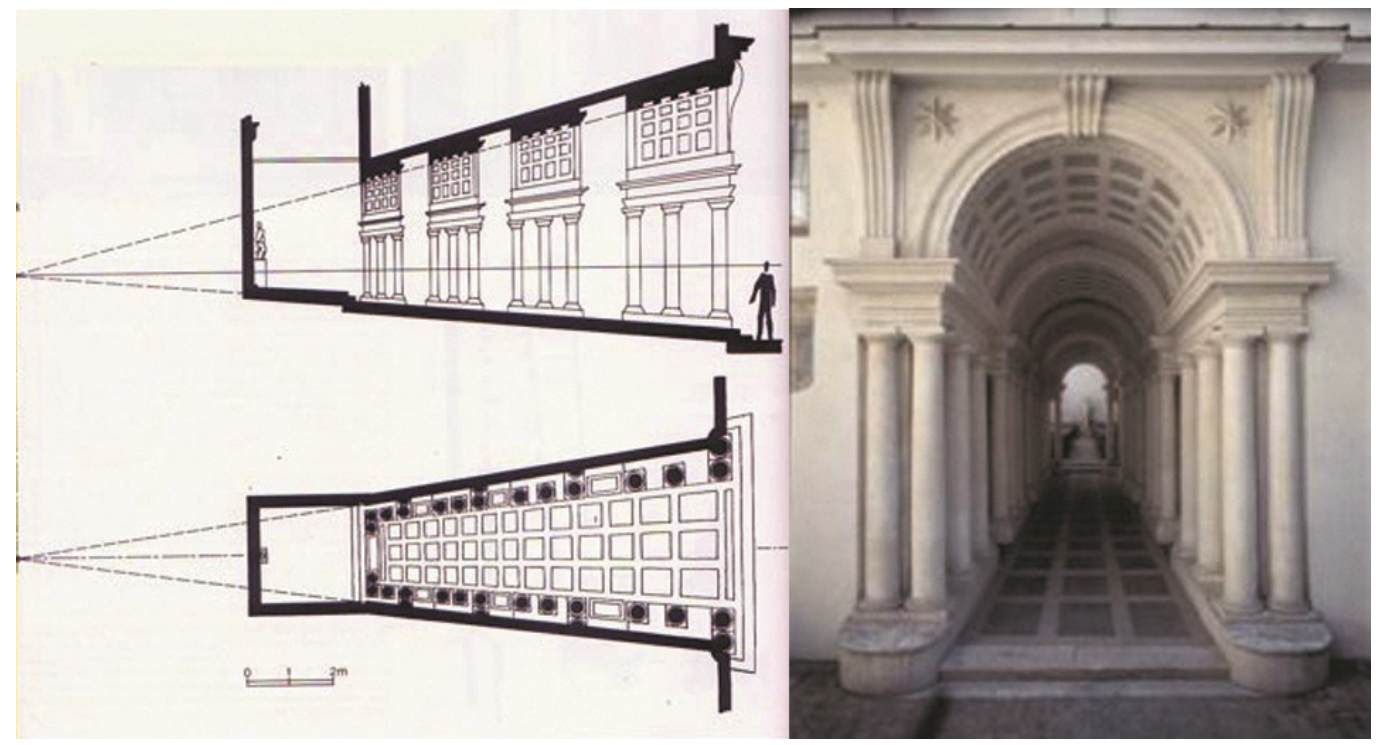

illusion of a gallery 37 meters long (actually only 8 meters). At the bottom of the gallery, in a garden lit by the sun, there is a sculpture that seems life-size, while it is only $60 \mathrm{~cm}$ high. Everything communicates, everything interacts, everything is part of the scene, stimulating the invisible to the eye, imagining almost a real open-air theatre. Through the disciplinary methodologies of the architectural survey and the geometric-configurative graphic analysis, the spatial layout of the I 8th century Neapolitan stairs is investigated, paying attention to the type of well-staircase. The most active architect who applies this construction method is certainly Ferdinando Sanfelice ( 675 - | 748), although he was contemporary and antagonist of Domenico Antonio Vaccaro on the Neapolitan architecture scene during the first half of the 18th century [Zerlenga 2015]. It differs from Vaccaro (who focuses on decorative elements), for his search for new spatial forms and attention to the structural aspect. He designed open staircases, real perspective sceneries that are distinguished from the existing Neapolitan palaces. The comparison with the closed spaces induces Sanfelice to seek daring solutions, taking advantage of the possibility of creating a stairwell with a central open stairwell and not supported by columns: the system is characterized by a suggestive design research and which gives internal space compared to the outside by clamping the steps to the side walls only, and leaving a central void (called the well). In this way the steps become 'cantilevered' and the staircase becomes self-supporting [Zerlenga 1993; Zerlenga 2017; Zerlenga 2019]. 


\section{The well staircases in Naples}

Through the campaign of architectural and photographic survey of countless Neapolitan eighteenth-century stairs operated by Ornella Zerlenga (figs. 3-6) [Zerlenga 20I8, p. 87] and analyzing the geometric conformation of the reference staircases it's clear that geometry is shaped both by necessity and by the aesthetic taste of those who designed them. Palazzo Palmarice (fig. 3) was one of the first buildings subjected to an adaptation of spaces, in fact a magnificent staircase was built from a simple form. Its base is the square, opened by the rounded corners, rotated $45^{\circ}$. This solution allows to obtain triangular landings covered by spindles, while the inner surface of the ramps is composed of Roman-style vaults in use in southern Italy and especially in Rome to support the flight of stairs, a solution that allows to obtain a different point of view of the staircase. Subsequently the shapes are adapted to other needs, changing, and obtaining different solutions. The staircase of Palazzo Bartolomeo di Majo (fig. 4) located in Piazza Vittoria, n.6 corner via Arcoleo in Naples, is the only one that presents itself with a geometric matrix with the shape of an ellipse, while in the case of Palazzo di Majo (fig. 5) is inscribed in a rectangle, thus obtaining a shape tending to the square even though it has a rhombic plan with concave sides, a concept no longer present in the stair located in via Tommaso Caravita, n. I4, Naples (fig. 6).

Fig. 3. Pictures of the entrance hall (Google images), staircase of the (architectural survey coor dinated by Ornella Zerlenga with R. De Gregorio, G. Del Gaudio).
Fig. 4. Staircase of Palazzo Di Majo at Piazza Vittoria Naples architectural survey (architectural and photographic survey coordinated by Ornella Zerlenga with R. Soreca, R. Santi, G. Puca).
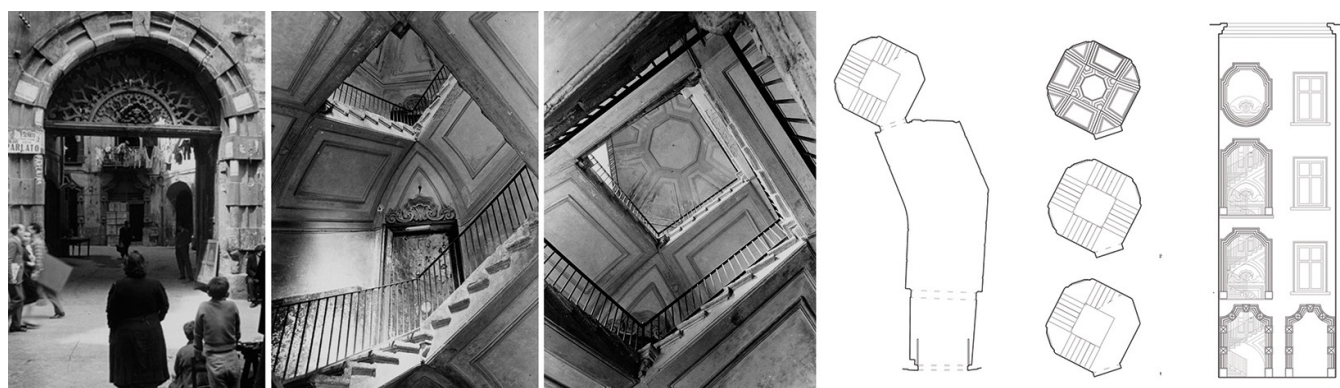

The same result is obtained for the staircase in the film Miseria e Nobiltà, (figs. 7-8), which has no curves and its resultant has a linear basis. It seems that the scenographers Alberto Boccianti, (Tuscan and scenographer of the director and screenwriter Mario Mattoli) and Piero Filippine (Neapolitan), took inspiration from the ancient Neapolitan palaces, reconstructing and re-proposing their interpretation of the structure in the theatre. From the analysed frames, the ramps and the regular structure appear. The same thing does not happen with the vaults, which probably have not been realized. Despite this, the self-supporting structure, of exceptional craftsmanship, continues to mantain its charm. In fact, due to its spatial characteristics, it was an inspiration and used as a scenography. An example is
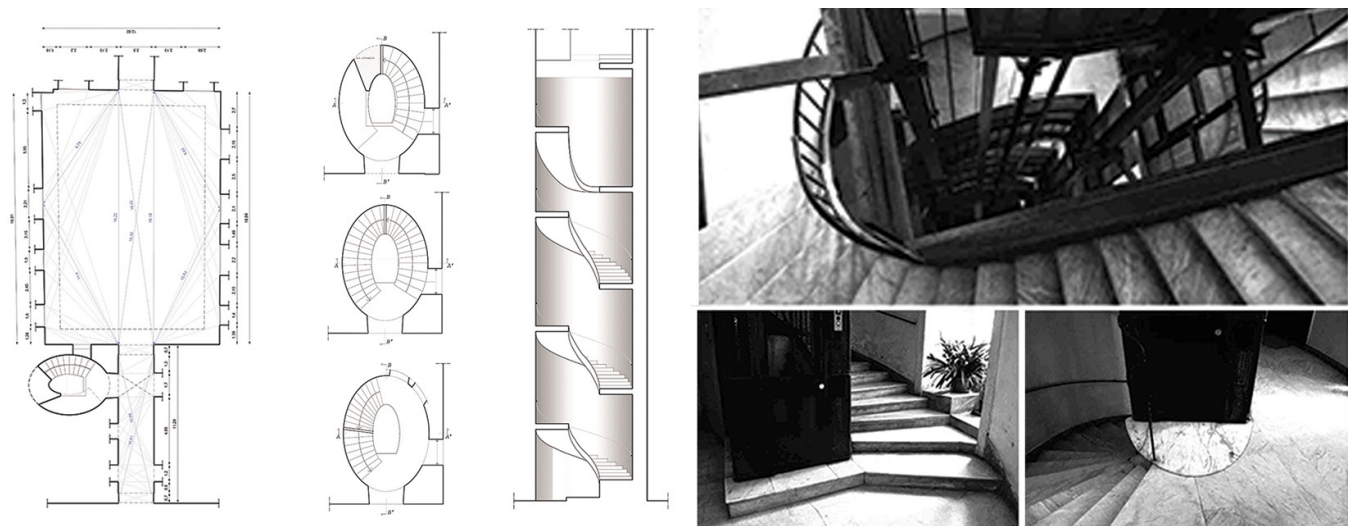
Fig. 5. Pictures of the staircase of Palazzo Di Majo (descent at Sanità) V. Marzocchella) Naples (architectural survey coordinated by Ornella Zerlenga with V. Laezza, R. iguori, G. Marino).
Fig. 6. Pictures of the staircase of Palazzo in Via Tommaso Caravita, I4, (V. Marzocchella) Naples (architectural survey coordinated by Ornell Zerlenga with P. Guarino, T Noviello, S. Mariano, Mariniello).
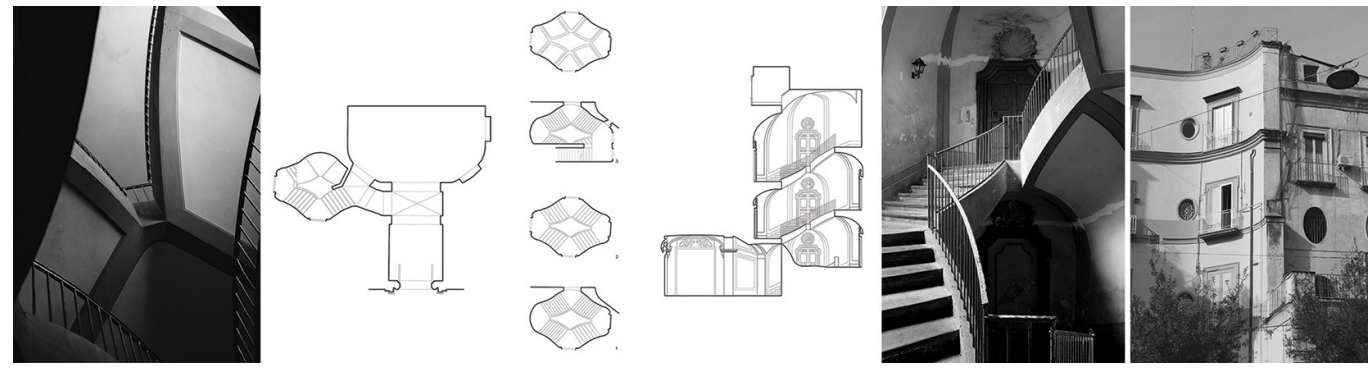

the staircase in via Tommaso Caravita, filmed in the scenes of L'Oro di Napoli (1945) (in six episodes and more precisely in the fifth, entitled Teresa, where you can admire the staircase without the occlusion of the lift). Its dam is the closest to the case study of the staircase of the film Miseria e Nobiltà. The Neapolitan open staircase is, at the same time, a space which represents several factors that are realized and manifested in it. By adding the scenery and the actors, we obtain a set of unusual elements, always new. The architecture of solids and voids, with the well staircase, creates a harmonious and ever-changing result. A mutation that years later becomes a necessity with the use of the lift. Some (elevators) obstruct the spatial sequence (portal-entrance hall-courtyard-staircase-garden) of the Neapolitan open stairs, as in the case of the staircase in via Tommaso Caravita, the elevator occupies the
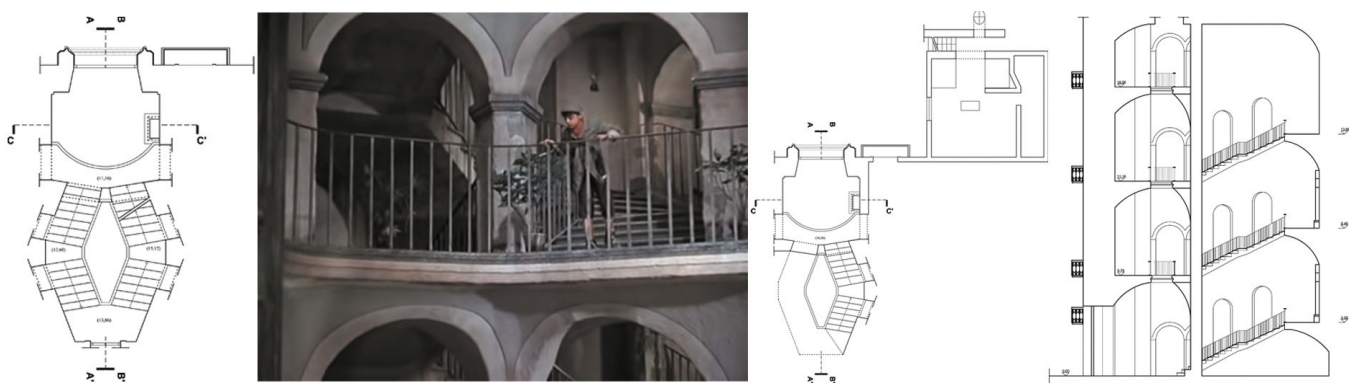

centre of the staircase, the distinctive element of the type of well staircase giving life to a new concept of collective fruition. By focusing attention in a small space, a further intimate but useful point of view is created as a space (scene) for immersive events supported by new technologies. The research provides for developments: the examined architecture can become a place open to the public where to organize cultural events, and also it can be proposed elsewhere through the help of new technologies such as augmented or virtual reality, allowing another audience to access information through a plurality of senses and to interact with the database in real time. The research has the goal not only to catalogue or to know the architectural value of the place examined, but also to return these architectural artefacts to the public. It wants to propose the scientific and poetic concept in a modern key, with the help of new technologies, obtaining a cultural consolidation to be linked to the themes of collective fruition and cultural regeneration on a national scale with possible international extensions.
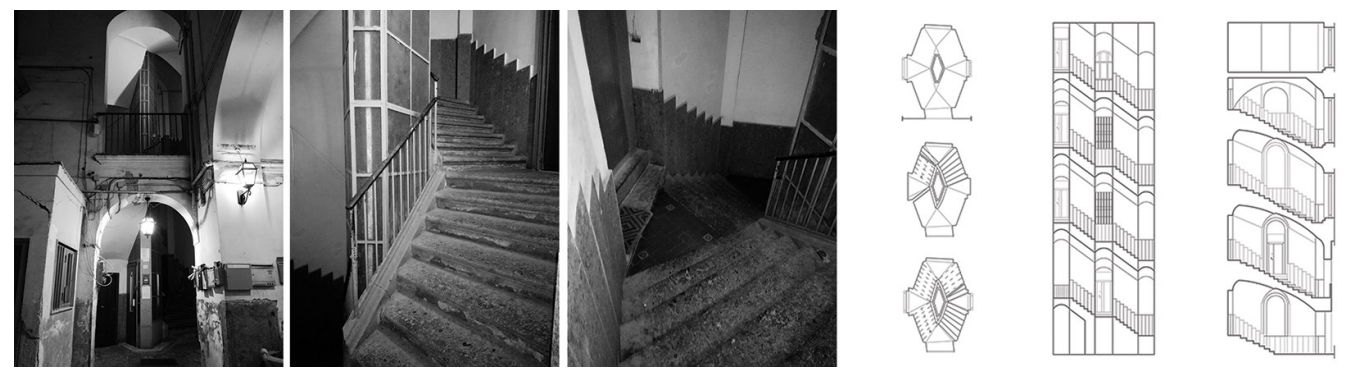


\section{The Research Project}

As can be seen from Morrice, R. (1983), there are stairways with a similar conformation even outside the Neapolitan context, even earlier than those of Sanfelice, such as that of the Abbey of San Florian in Linz, in Austria (1709) (fig. 9a), the porch staircase to the Rathaus Possneck in Turigia (1530-3I) (fig. 9b), the staircase in the courtyard of the Breda Castle in Holland built by Thomas Vinidor (1535-38) or the staircase on the sides of the entrance to the main courtyard of Baranow Castle in Poland (1591-1606). These examples allow to structure a broader research project, concerning not only the Neapolitan context, but which can also be applied in other Italian and international contexts. The analysis conducted by the research leads to the search of new methodologies to enhance this type of architecture which, over the centuries, have maintained their scenographic character. Even the impactful addition of the lift can be a further starting point to generate new flows and points of view. The cinema and theatre of the twentieth century had managed to bring the scenes of daily life that took place within these spaces to a wider audience. Now, with the help of new technologies (such as augmented reality or video mapping) and applying the recent need to enhance existing spaces rather than create new ones, the transition from private to public sphere can take place by bringing visitors inside the courts to take part to virtual shows that overlap different realities on the real environment. The staircase becomes once again the backdrop of a stage: theatrical representations will be projected onto it through video mapping (or augmented reality) which will merge with real situations. The elevator sometimes placed inside the well, other times placed outside, can be used as a means of observing the scene from other points of view or as a prop that, moving, will create new spatial perceptions. For its realization, the project is articulated in some preliminary steps: the survey of the staircases have been made with the help of new technologies based on

Fig. 8. Render of the staircase of the film Miseria Nobiltà. Characters: First floor Peppiniello; second floor Don Felice, Don Pasquale, La Piemontese third floor Donna Luisella. Image extracted from the film. extracted from th ilm. Peppeniello on the landing overlooking the ration by V. Marzocchella)
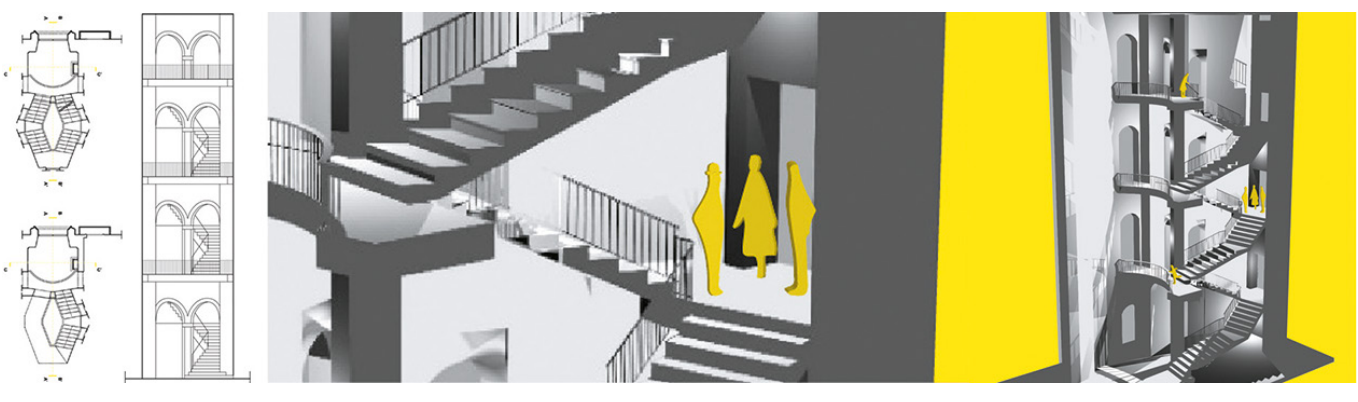

laser scanner and photogrammetry, which have allowed to reconstruct the three-dimensional models with extreme precision, the models have been optimized with the most recent version (2.82) of the open source software Blender3d, which allows easy management of the meshes obtained from the survey. The three-dimensional models serve as a basis on which virtual objects (the protagonists of the show) overlap. They will interact with the real space occupied by the staircase. One of the ideas matured by the research, about the Neapolitan context, is to stage the comedy of art with its masks and its characters, using advanced 3D modelling. The masks were created using the Sculpting technique which shows all its potential in the latest version of Blender $3 \mathrm{~d}$. In fig. I 0 is illustrated (by way of example) the Sculpting technique used for modelling the face of Pulcinella: using different chisels it is possible to sculpt a three-dimensional object in the desired shape. The research is still in an embryonic phase and the next phase will be to animate the models to give life to the show. Real actors and sound orchestras may be involved. In order to view the scenes inside the courts, augmented reality could be applied using the image of the staircase as a marker, but the interesting hypothesis is to use the video mapping technique and project animations or videos directly on the stage backdrop. Transversal events to the show, such as temporary exhibitions or guided tours, could bring spectators inside the courtyards to learn more about this type of architecture. 


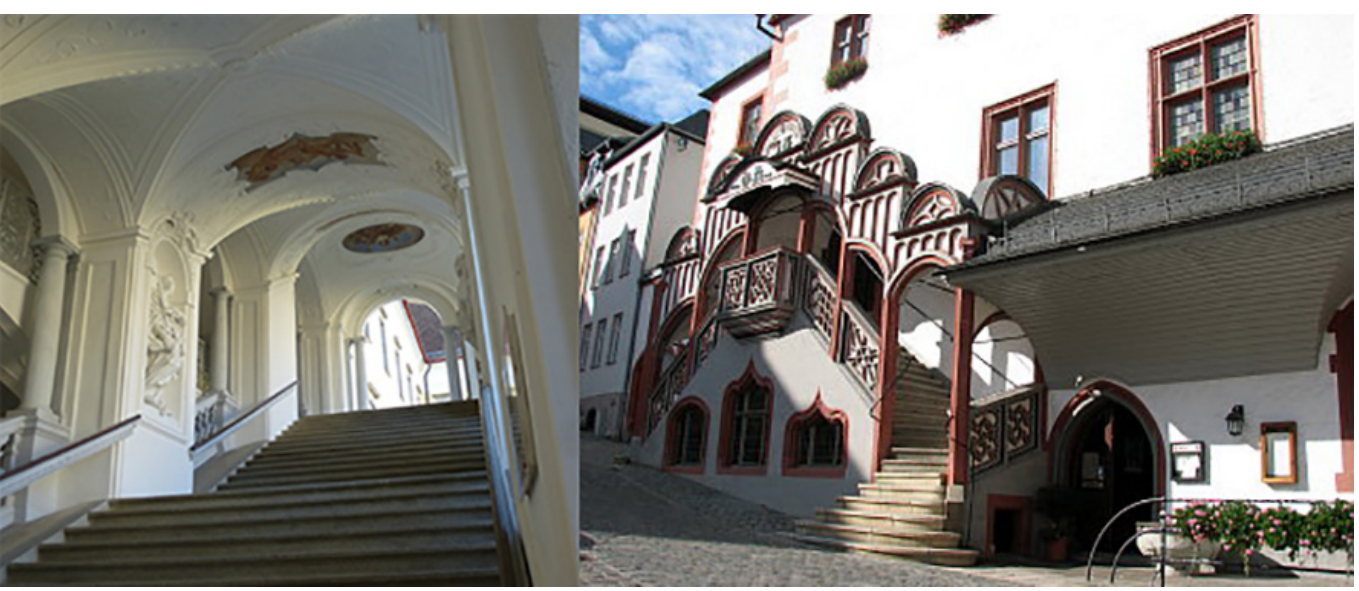

\section{Conclusions}

"Il tono di una città è dato [...] da quella che si può chiamare la sua letteratura architettonica, l'espressione di una continuità ambientale nel pratico svolgimento della vita urbana con le sue peculiarità di costume e di folclore; nel riecheggiamento artigiano e popolare dell'arte aulica; in quello che si suole comunemente dire il colore locale e che non è una pura accidentalità destinata a fornire pittorici spunti, ma il volto stesso della storia nella sua stratificazione, la presenza viva del passato nella sua forma più generale" [Pane 2007].

A city like Naples cannot be known only through its main monuments because they often do not represent the real protagonists of everyday life. In his publication he focuses on all those artistic and architectural expressions considered minor but very important to characterize the city. This project has the aim of enhancing the hidden heritage of the city of Naples and making the work of Sanfelice better known, but the intent is to apply the same methodology also to other contexts (such as those mentioned above), therefore bring this type of theatrical performances also outside the Neapolitan context, drawing on local traditions and cultures [I].

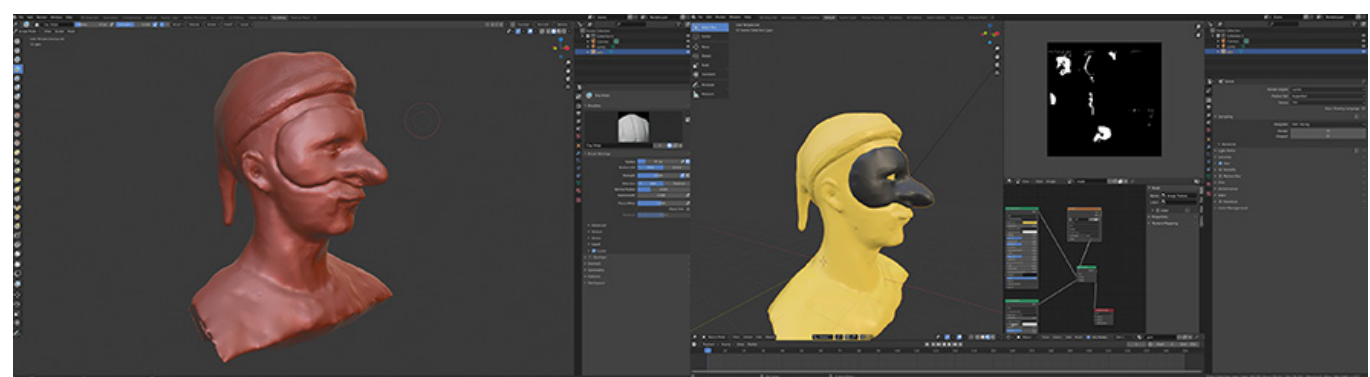

\section{Notes}

[I] Valeria Marzocchella wrote the paragraphs: Introduction, Dialogue and Environment: architectural environment of the access system, The well staircases in Naples. Maurizio Perticarini wrote the paragraphs: The Research Project, Conclusions.

\section{References}

Capobianco Michele (1962). Scale settecentesche a Napoli. In L'architettura. Cronache e storie.VIII, 6, pp. 40 I-4I 7.

Cirillo Vincenzo (2017). Istruzioni diverse di modelli e forme del salire. La scala fra teoria, principi e maestri. In di Luggo Antonella et al. (a cura di). Territori e Frontiere della Rappresentazione. Atti del $39^{\circ}$ Convegno Internazionale dei Docenti della Rappresentazione. Napoli I4-I6 settembre 20 17. Roma: Gangemi Editore, pp. 30 I-3 I0. 
Cirillo Vincenzo (2019). Riflessioni e suggestioni fra geometria e forma. Le scale del '700 napoletano | Reflections and suggestions between geometry and form. The Neapolitan staircases of eighteenth century. In Temi e frontiere della conoscenza e del progetto, vol. 7, pp. 256, Napoli: La Scuola di Pitagora.

D'amico Silvio ( 1970). Teatro, Storia del teatro drammatico, II teatro contemporaneo. Milano: Garzanti.

De Dominici Bernardo (1744). Vite dei pittori scultori ed architetti napoletani. Ed. I846, vol. IV, Napoli: EAN.

de Rubertis Roberto (2017). Verso quale rappresentazione? In In di Luggo Antonella et al. (a cura di). Territori e Frontiere della Rappresentazione. Atti del $39^{\circ}$ Convegno Internazionale dei Docenti della Rappresentazione. Napoli I4- I6 settembre 2017. Roma: Gangemi Editore, pp. 3-5.

di Luggo Antonella (20 I0). Struttura e forma: le superfici voltate nelle scale aperte napoletane. In AAVV. Disegnare il tempo e l'armonia. Firenze: Alinea Editrice, pp. 394-399.

di Luggo Antonella et al. (20 I I). Palazzi napoletani. Itinerari grafici e percorsi interpretativi nel rilievo dell'architettura. Napoli: Giannini Editore.

Docci Mario, Chiavoni Emanuela (2017). Saper leggere l'architettura. Bari: Laterza.

Ferraro Italo (2006). Napoli, Atlante della città storica. Dallo Spirito Santo a Materdei. Napoli: Oikos.

Gambardella Alfonso, Amirante Giosi (1994). Napoli fuori le mura. La Costagliola e Fonseca da platee a borgo. Napoli: Edizioni Scientifiche Italiane.

Gambardella Alfonso (2004). Ferdinando Sanfelice. Napoli e l'Europa. Napoli: Edizioni Scientifiche Italiane.

Marzocchella Valeria (2019). Dialoghi attraverso la scala a pozzo. Un esempio di scala sanfeliciana nel film Miseria e Nobiltà (1954). Napoli: La scuola di Pitagora.

Marzocchella Valeria (a cura di). (2019). Sovrastrutture. Suono del presente, proiezione del futuro. Napoli: La scuola di Pitagora.

Migliari Riccardo (2003). Geometria dei modelli. Rappresentazione grafica e informatica per l'architettura e il design. Roma: Kappa.

Morrice R.J. ( 1983). Sanfelice and St Florian: Indigenous tradition and staircase design. In Architectural History, pp. 26, 82-86.

Pandolfi Vito (1964). Storia universale del teatro drammatico. Torino: Unione Tipografico Editrice Torinese.

Pane Roberto (1939). Architettura dell'età barocca in Napoli. Napoli: Editrice politecnica.

Pane Roberto (2007). Napoli Imprevista. Napoli: Grimaldi \& C. Editori.

Sacchi Livio (1994). L'idea di rappresentazione. Roma: Edizioni Kappa.

Sgrosso Anna (1979). Lo spazio rappresentativo dell'architettura. Napoli: Massimo.

Zerlenga Ornella et al. (2019). La escalera del Palacio Persico en Nápoles: análisis geométrico, constructivo y mecánico. In: Huerta Santiago et alii (a cura di). Actas del Undécimo Congreso Nacional de Historia de la Construcción. Soria: Imprenta Provincial de Soria, pp. 303-310.

Zerlenga Ornella (a cura di). (20 18). M'illumino d'immenso. La scala del palazzo Cassano Ayerbo d'Aragona. Napoli: La scuola di Pitagora.

Zerlenga Ornella (2017). La scala 'vacua nel mezzo'. Due esempi napoletani a confronto. In Antonella et al. (a cura di). Territori e Frontiere della Rappresentazione. Atti del $39^{\circ}$ Convegno Internazionale dei Docenti della Rappresentazione. Napoli I4-I6 settembre 20 17. Roma: Gangemi Editore, pp. I161-1168.

Zerlenga Ornella (2016). Disegnare le ragioni dello spazio costruito. Le scale aperte del '700 napoletano. In Bertocci Stefano, Bini Marco (a cura di). Le ragioni del Disegno. The reasons of drawing. Atti del $38^{\circ}$ Convegno Internazionale dei Docenti della Rappresentazione. Napoli 14-16 settembre 2017. Roma: Gangemi, pp. 667-672.

Zerlenga Ornella (20I5). Le scale sanfeliciane a Napoli. In Giovannini Massimo, Arena Marinella, Raffa Paola (a cura di). Spazi e culture del Mediterraneo 4. Costruzione di un atlante del patrimonio culturale mediterraneo. Napoli: La Scuola di Pitagora, pp. 237-244.

Zerlenga Ornella (20I4). Staircases as a representative space of architecture. In Gambardella Carmine (a cura di). Le vie dei Mercanti, XII Forum Internazionale di Studi. Napoli: La scuola di Pitagora, pp. I632- 642.

Zerlenga Ornella (20 I 3). Memories in stone. In Gambardella Carmine (a cura di). Heritage Architecture LanDesign. Napoli: La scuola di Pitagora, pp. 245-255.

Zerlenga Ornella (2000). Criteri e metodi per rilevare, conoscere e rappresentare livelli differenziati di complessità. II sistema degli accessi al costruito storico residenziale napoletano. In Cundari Cesare, Martone Maria (a cura di). La normazione nella rappresentazione dell'edilizia. Roma: Kappa, pp. 307-310.

Zerlenga Ornella (1993). La scala nel banco di tufo. In Penta Rosa (a cura di). Lo spazio del disegno. Napoli: II Notiziario Legale S.r.l., pp. 68-78. 


\section{website}

https://www.futuro-europa.it/20493/cultura/miseria-nobilta-film- I 954.html.

https://www.dailymotion.com/video/x6gk8as.

https://napoli.itineraridellacampania.it/home/page/32/.

https://www.youtube.com/watch? $v=0$ Lfazabg|RM.

https://paolareghenzi.it/principi-della-composizione/ che-cose-la-pre-produzione/\#gref.

https://www.teatrodinessuno.it/scarpetta/miseria-nobilta.

https://www.capitolivm.it/societa-romana/la-domus-romana/.

https://immagineperduta.it/micene-storia-mito/.

https://restaurars.altervista.org/la-galleria-prospettica-borromini-galleria-spada/https://palazzoducale.visitmuve.it/it/il-museo/lasede-e-la-storia/sede/.

https://napolipiu.com/i-magnifici-retroscena-di-miseria-e-nobilta-svelati-da-peppeniello.

\section{Authors}

Valeria Marzocchella, Università della Campania “Luigi Vanvitelli", valeria.marzocchella@unicampania.it

Maurizio Perticarini, Università della Campania “Luigi Vanvitelli", maurizio.perticarini@unicampania.it

To cite this chapter. Marzocchella Valeria, Perticarini Maurizio (2020). New technologies of cultural regeneration. An exemple of Sanfelice staircase as a place of comunication. In Arena A., Arena M., Brandolino R.G., Colistra D., Ginex G., Mediati D., Nucifora S., Raffa P. (a cura di). Connettere. Un disegno per annodare e tessere. Atti del $42^{\circ}$ Convegno Internazionale dei Docenti delle Discipline della Rappresentazione/Connecting. Drawing for weaving relationships. Proceedings of the 42 th International Conference of Representation Disciplines Teachers. Milano: FrancoAngeli, pp. $x \times x \times x$ 